\title{
Promoting universal financial protection: a policy analysis of universal health coverage in Costa Rica (1940-2000)
}

\author{
Juan Rafael Vargas and Jorine Muiser ${ }^{*}$
}

\begin{abstract}
Background: This paper explores the implementation and sustenance of universal health coverage (UHC) in Costa Rica, discussing the development of a social security scheme that covered 5\% of the population in 1940, to one that finances and provides comprehensive healthcare to the whole population today. The scheme is financed by mandatory, tri-partite social insurance contributions complemented by tax funding to cover the poor.
\end{abstract}

Methods: The analysis takes a historical perspective and explores the policy process including the key actors and their relative influence in decision-making. Data were collected using qualitative research instruments, including a review of literature, institutional and other documents, and in-depth interviews with key informants.

Results: Key lessons to be learned are: i) population health was high on the political agenda in Costa Rica, in particular before the 1980s when UHC was enacted and the transfer of hospitals to the social security institution took place. Opposition to UHC could therefore be contained through negotiation and implemented incrementally despite the absence of real consensus among the policy elite; ii) since the 1960s, the social security institution has been responsible for UHC in Costa Rica. This institution enjoys financial and managerial autonomy relative to the general government, which has also facilitated the UHC policy implementation process; iii) UHC was simultaneously constructed on three pillars that reciprocally strengthened each other: increasing population coverage, increasing availability of financial resources based on solidarity financing mechanisms, and increasing service coverage, ultimately offering comprehensive health services and the same benefits to every resident in the country; iv) particularly before the 1980s, the fruits of economic growth were structurally invested in health and other universal social policies, in particular education and sanitation. The social security institution became a flagship of Costa Rica's national development strategy which reinforced its political importance and contributed to its longer-term sustainability and that of UHC.

Conclusions: UHC has been achieved in Costa Rica because it was supported at the highest political level within a favourable socio-economic and political context. Once achieved, UHC became an entitlement for the population and now enjoys broad public support.

Keywords: Health policy, Social protection, Universal health coverage

\section{Background}

Universal health coverage (UHC) is high on the global health agenda [1]. In particular, low- and middle-income countries are explicitly encouraged by the global health community to move towards UHC despite their relatively scarce resources. Within this context it is useful to explore how some of these countries have already moved in that direction. The analysis in this paper focuses on

\footnotetext{
* Correspondence: jorine.muiser@gmail.com
} Universidad de Costa Rica, San José, Costa Rica the process that took place in Costa Rica between 1940 and 2000 during which time UHC was achieved. The scheme has been sustained until today with $88 \%$ of the 4.6 million Costa Ricans being covered since the 1990s. Today, total health spending represents $11 \%$ of GDP in Costa Rica with public health spending accounting for around $70 \%$ [2]. Since 2000, total health expenditure has increased rapidly, mainly in the form of private health expenditure.

Three consecutive health reform periods mark Costa Rica's UHC development process between 1940 and 
2000. During the first period (1940-1960), the social security fund (Caja Costarricense de Seguro Social, CCSS) was founded based on social protection for manual and 'white-collar' workers. The scheme was included in the country's Constitution from the outset. During the second period (1961-1980), the CCSS was mandated to make its coverage universal within a period of 10 years. The Hospital Transfer Act of 1973 transformed the CCSS from a merely financing institution into the main hospital care provider in the country. At the time, primary health care was being provided by the Health Ministry, particularly in marginal urban centres and rural areas. During the third period (1981-2000), primary health care was integrated into the CCSS scheme through the establishment of health posts throughout the country in proportion to the population. From that moment on, the Health Ministry would strengthen its role as health system steward, which it already had in formal terms since 1983. By the end of the century, Costa Rica had evolved into an upper-middle economy, and the CCSS transformed into the single, universal and comprehensive health care financer and provider it is today.

Costa Rica's achievements in terms of UHC may seem straightforward, but the road was long and rough. The objective of the analysis presented in this paper is to identify key actors in the three consecutive health reform periods, their relative influence in the health policy process and the context in which they operated; remaining challenges are also defined.

\section{Methods}

Qualitative methods were used to collect data, including a review of the literature (published research, grey literature, newspaper articles and formal, institutional documents), as well as two sets of interviews with a total of 47 key informants and one focus group discussion. The literature was used to understand the historical context of the three health reform periods and the institution building process related to the achievement of UHC, as well as to collect statistics showing progress over time in terms of economic development, population coverage, and health system financing and outcomes.

The first set of open-ended interviews was used to identify historic landmarks and events as well as key actors in the three consecutive health reform processes. A total of 29 interviews were carried out with three groups of informants: key policy actors (former Ministers and CCSS CEO's), key CCSS and Ministry of Health officials (at different levels and responsibilities), and researchers in relevant fields. Questions focused on the political agendas of the different actors, their relative power, the changes occurring due to social and economic contextual factors, and the degree of development of the health system. Reich's actor mapping framework [3], a software program specifically designed to undertake actor mapping as part of policy analysis, was used to record the informants' views and statements. The software produced a table as output that helped identify actors and explore their relative political power in the policy process.

The second set of semi-structured interviews was used to deepen information about the actual role of the key actors, the way they coordinated their actions, how the UHC policy was actually implemented and future challenges. The interviewees were policy and institutional actors all of whom had participated in one or more of the health reform processes: ex-health ministers, ex-CCSS CEO's, Health Ministry or CCSS officials, private sector health professionals, policy analysts and beneficiaries. The focus group formed part of this second set of semi-structured interviews, using an interview guide with the same topics. The group consisted of four medical doctors, two each from the Ministry of Health and the CCSS. The topics that guided the semi-structured interviews and focus group also informed the literature review and coding exercises.

Walt and Gilson's framework [4] was applied and an analysis was undertaken of the context, content and process of the reforms. Following this framework, the content of the policy is important but the focus of the analysis is on how these policies are implemented, i.e., the process. The objective of the analysis is to understand key actors' behaviour within the margins of those formal rules and given their specific context.

Responses were compared across interviewees and with statistics and information from other sources. This facilitated the triangulation of the information retrieved from different sources to identify the most widely supported arguments.

Ethical approval was obtained from the University of Costa Rica and WHO, and all interviewees and focus group discussion participants signed an informed consent form.

\section{Findings about the process of UHC development}

Key informants explained, and literature confirms, that Costa Rica started to develop its democratic social investment approach in the $1890 \mathrm{~s}$ focusing mostly on education policies. While the country was poor and isolated, its policy elite, having often studied abroad, sought to modernize it. Up to 1940 s, there was slow and limited economic growth with three noteworthy developments: i) primary education was made compulsory in 1888, ii) the Ministry of Health was established in 1922, and iii) democratic institutions started flourishing [5-7].

\section{First period of major reform}

The 1940s brought the first major phase of health reform when President Calderon founded the CCSS. This public, autonomous institution started by providing 
health and pension benefits only to manual and 'whitecollar' workers living in urban areas. Medical doctors opposed the move fearing they would lose their niche of the market and started a labour union. The CCSS was also not welcomed by some members of the Cabinet and many others across the political spectrum, as depicted in Figure 1. Despite this opposition, President Calderon created a coalition of actors to support the reform; he was crucially important in the reform being adopted as he enjoyed a lot of power (black background in Figure 1). At the other end of the spectrum the physicians' labour union strongly opposed the reform, but it had less power. Their opposition to the scheme was resolved by negotiation, whereby they would be allowed to work as public sector employees for the CCSS while keeping their private practices open as well. Other actors, for example the press and Congress, are in the middle of the figure because they had no strong interest in the reform, as key informants confirm.
Key indicators for the end of the first ten years of institution building serve as a baseline against which to benchmark the impact of later developments. By 1950, the total population of Costa Rica was almost one million, with youth (0-15 years age) and elderly (65 years and older) representing $43 \%$ and $3.4 \%$ of total population, respectively. Total fertility was 6.7 per woman and life expectancy at birth 56 years for both sexes. Health care expenditure was $2.2 \%$ of GDP and the CCSS covered around $8 \%$ of the population [8]. A weak, but growing health system had begun to develop as is further shown in Table 1 and Figure 2.

\section{Second period of major reform}

Thirty years from the founding of the CCSS, the socioeconomic and epidemiological context had changed and a window of opportunity opened for the second reform. Four noteworthy features mark this period: i) the economy expanded (6\% annual growth on average with stable
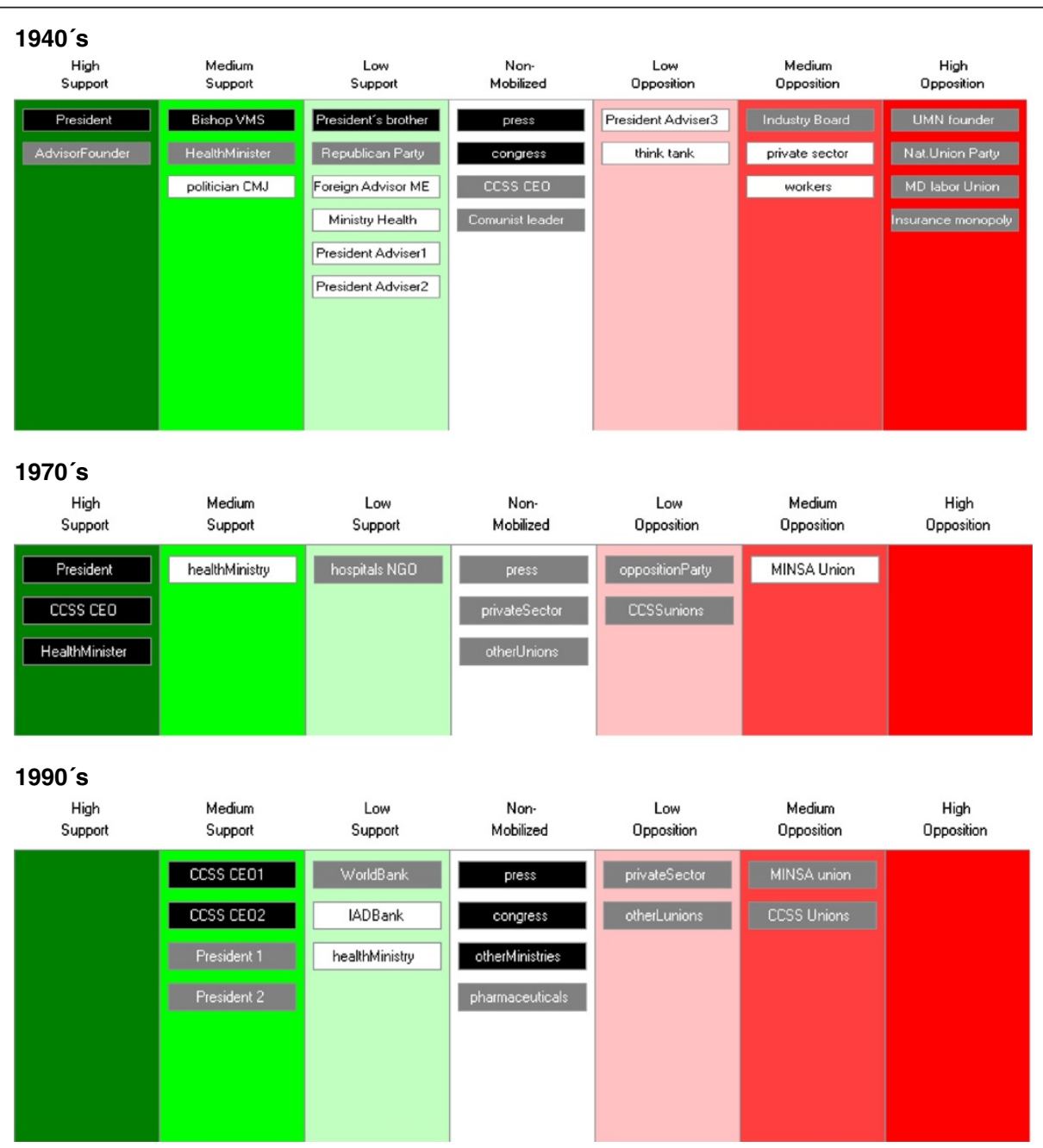

Figure 1 Key actors behind the reforms. Source: Elaboration by authors. 
Table 1 Milestones in the making of Costa Rica's national health system, 1941-2010

\begin{tabular}{|c|c|c|}
\hline Year & Policy measure & Coverage \% \\
\hline 1941 & $\begin{array}{l}\text { CCSS is founded, providing health insurance } \\
\text { for urban workers with wages up to } \\
\$ 52.63 \text { a month }\end{array}$ & 3.0 \\
\hline 1949 & $\begin{array}{l}\text { The new Constitution retains the three-fold } \\
\text { symmetrical financing (employers, workers } \\
\text { and government); management remains } \\
\text { at CCSS }\end{array}$ & 6.8 \\
\hline 1954 & Health insurance covers the spouse & 11.9 \\
\hline 1959 & The salary ceiling rises to $\$ 149.25$ a month & 15.1 \\
\hline 1961 & $\begin{array}{l}\text { Insurance coverage is declared universal with } \\
\text { a ten year grace period }\end{array}$ & 17.7 \\
\hline 1962 & Health insurance was extended to rural workers & 20.3 \\
\hline 1965 & $\begin{array}{l}\text { Health insurance was extended for the } \\
\text { whole family }\end{array}$ & 30.6 \\
\hline 1970 & Phasing out the salary cap & 47.1 \\
\hline 1971 & $\begin{array}{l}\text { Compulsory retirement insurance affiliation } \\
\text { for all workers }\end{array}$ & 51.5 \\
\hline 1972 & Health insurance for college students & 53.8 \\
\hline 1973 & $\begin{array}{l}\text { All private hospitals are transferred to CCSS; } \\
\text { government pays health insurance for } \\
\text { extreme poverty citizens }\end{array}$ & 58.4 \\
\hline 1974 & Retirement insurance to all elderly poor & 60.3 \\
\hline 1975 & $\begin{array}{l}\text { Voluntary health insurance and retirement } \\
\text { insurance coverage }\end{array}$ & 59.6 \\
\hline 1976 & $\begin{array}{l}\text { Retirees under special schemes become eligible } \\
\text { for health insurance }\end{array}$ & 61.8 \\
\hline 1984 & $\begin{array}{l}\text { Insurance arrangement under presumptive } \\
\text { income (for self-employed and farmers) }\end{array}$ & 83.9 \\
\hline 1995 & $\begin{array}{l}\text { Compulsory health insurance for retirement } \\
\text { insurance retired workers }\end{array}$ & 86.4 \\
\hline 1996 & Universal student health insurance & 89.7 \\
\hline 2001 & $\begin{array}{l}\text { Worker Protection Act grants new legal } \\
\text { instruments against tax evasion and forces } \\
\text { self-employed to join the health insurance } \\
\text { scheme }\end{array}$ & 87.5 \\
\hline 2005 & $\begin{array}{l}\text { Health insurance for vulnerable people } \\
\text { (poor, indigenous and rural poor) paid by } \\
\text { Government }\end{array}$ & 87.6 \\
\hline
\end{tabular}

Source: Adapted from Rodríguez A., Working Paper for Estado de la Nación, 2010 [9].

inflation); ii) social democracy was shaping government (both in terms of legislation and organizational development); iii) the fight against infectious diseases was successful to the extent they were no longer the leading cause of death (Figure 2); and iv) good health care at low cost was being delivered [10]. The political context changed and new actors took the stage. The second health reform started with the 1961 Social Security Universalization Act.

The Act instructed the CCSS to universalize the scheme within a period of ten years. Table 1 demonstrates how new segments of the population were brought in one by one, ultimately resulting in near universal population coverage by the 1990s. Key informants explain the uniqueness of the process: "It was a very risky project as no other Latin American country had universal social insurance like the one we wanted to establish; and on top of that, it gave the Government the direct responsibility to realize this universal availability of medical services" (interview with former Health Minister). In most Latin American countries, social security was and still is reserved to formal sector workers whereas informal workers and the poor depend on the medical services provided by their respective health ministries. These generally neither guarantee availability of quality health care nor financial risk protection. During the past 20 years, UHC has risen on the health policy agenda across the region, but apart from Cuba and Brazil with their tax-based schemes, Costa Rica remains the only country with effective and equitable near universal health coverage based on social health insurance.

The 1973 Hospital Transfer Act was drafted by a thinktank at the Ministry of Health. The Act was a key step in the universalization process, as it recognized that universal health care needed all hospitals to accept and treat patients under uniform rules, medicines to be provided in a homogeneous way ${ }^{\mathrm{a}}$ and the whole population to be covered under the same conditions. Until then, there had been a loosely organized not-for-profit quasi-private hospital establishment owned and managed by the Social Protection Board, that was funded from lottery sales and operated through a mixture of charity and market norms. The CCSS at the time owned three hospitals along with a network of clinics. The Health Minister ${ }^{\mathrm{b}}$ knew a national hospital network was needed to achieve universal access to required care and financial protection, and while the politics were not simple, the Act was adopted ${ }^{\mathrm{c}}$. For the next decade, all of those hospitals were gradually brought under the control of the CCSS, a process that is unique within the Latin American region.

At the time, the CCSS did not have enough financial or human capital ${ }^{\mathrm{d}}$ to effectively maintain the national hospital network. It faced a financial predicament, not only because it was extending population coverage, but also because the Government did not always pay its portion of the tri-partite (employers, employees and the government) contribution arrangement agreed to in the 1940s. New financing mechanisms were implemented, including the elimination of the previously applied wage ceiling so that higher income workers would be drawn in; and the transfer of revenue from a new tax on cigarettes to the CCSS in the 1960s [6]. The accumulating debt by the government to the CCSS would become a recurrent problem. On the other hand, the Medical Union's resistance to the scheme faded away because the universal availability of medical services meant more employment for them, and as mentioned earlier, they had been allowed to keep their private practices open $[6,8,11]$. 


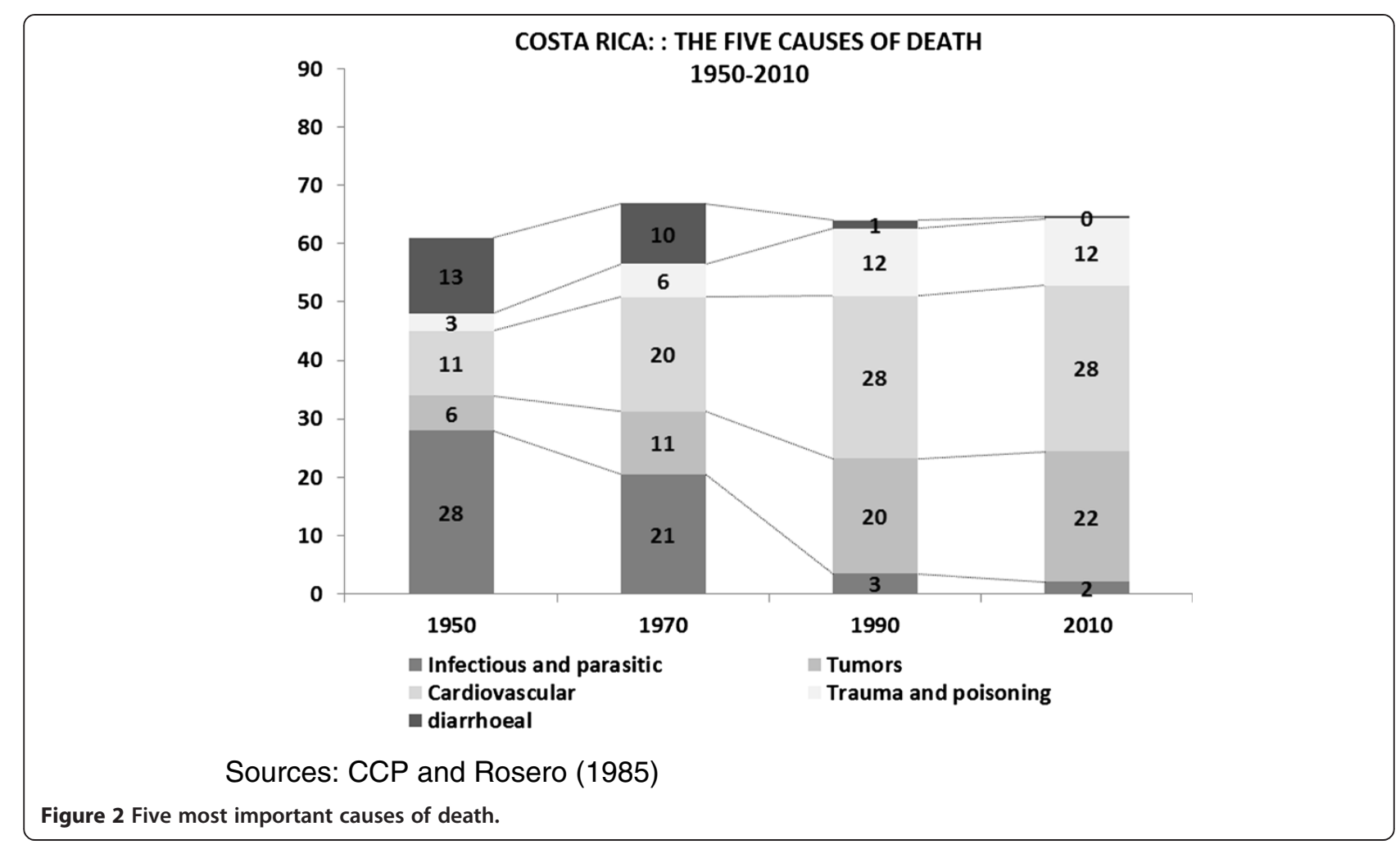

Similar to the first reform, the actors were spread across the political spectrum, as shown in the middle section of Figure 1. President Figueres played a crucial leadership role as the health policy struggle had deadlocked before he stepped in ${ }^{\mathrm{e}}$. A key informant confirmed that the President, in settling the debate on the Hospital Transfer Act with the aim to transform the CCSS into a kind of NHS, as the British tax-based Universal Health Coverage system is known, clarified his view in this way: "I want the Ministry and the CCSS working together, not fighting, as it was the tradition. This project would bring them together" (interview with former CCSS CEO). At that time, the Health Ministry maintained responsibility for the provision of primary health care and the idea was that it would start referring patients to the CCSS hospitals.

The middle section of Figure 1 shows that the opposition to the transfer of hospitals came in particular from the side of the labour unions and politicians who argued that the universal coverage process was uncontrollable. So did the CCSS management who feared that the transfer would financially cripple the institution, as no fees would be charged for services ${ }^{\mathrm{f}}$, and lottery funding would disappear. Their concerns also related to the tasks involved in growing from managing three single hospitals to a full hospital network covering the whole country. Even the Pan-American Health Organization ventured out of its technical role and voiced its opposition to the hospital transfer plan [11]. However, the Act was adopted and implementation initiated. Key informants agree: "The transfer of hospitals was enacted, it was part of the universalization plan. It was a political decision: why would the social security institution build its own hospitals? The transfer was a traumatic experience for many, but it was a decision taken with no consensus at that moment" (Focus group 1). Notably, in most Latin American countries except for Costa Rica, social security institutions did build their own hospitals further contributing to the development of highly fragmented and often inequitable health systems.

While it was no easy juncture, the far right section on Figure 1 being empty means that no actor was highly opposed to the reform. Key actors confirm that this was due to evidence on improvements in terms of equity and population health. Figure 3 maps the distribution of hospitals across the country since the 1980s.

Forty years of the CCSS contributed to demographic and epidemiological changes. The total population grew to approximately two million inhabitants. Elders and youth represented $3.8 \%$ and $46 \%$ of the total population, respectively, at a dependence rate peak. Infant mortality decreased to 21 per 1,000 live births; fertility rates to 3.7 per woman. CCSS population coverage grew nine-fold reaching $39 \%$ by 1980 . Babies were delivered at health facilities more than three times as often as in 1950 thus improving maternal mortality rates. The number of hospital 


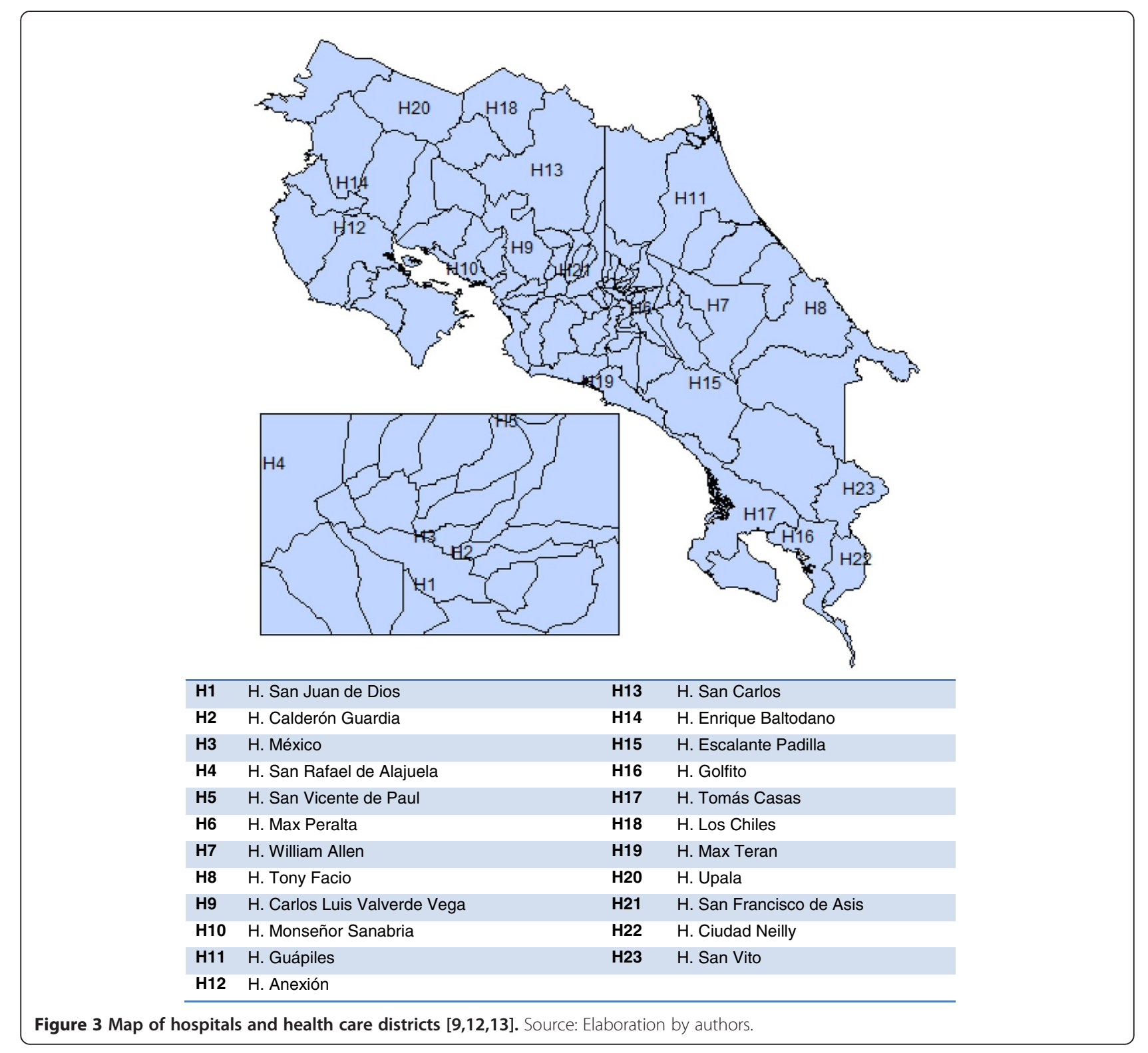

beds per inhabitant decreased by half, but the number of medical doctors almost tripled; life expectancy increased to almost 70 years at birth for both sexes [11]. Health care expenditure was $5.1 \%$ of GDP, with per capita real health expenditure 1.8 times higher than when the CCSS was founded. Importantly, the investments in health were accompanied by the implementation of other universal social policies as part of a wider national development strategy. The latter resulted in the population with access to water reaching $75 \%$ by 1980 , one and a half times higher than in 1950, and population with sanitation up to 86\% [8] (Table 1 and Figure 2). The socio-economic developments notably improved the lives of Costa Rica's inhabitants.

\section{Third period of major reform}

The third health reform was implemented during the 1990s when at the global level primary healthcare was the key strategy. The experiences from the hospital transfer process and lessons learnt from the primary healthcare delivery programs carried out by the Ministry of Health during the 1970s and 1980s, informed the design of a new primary healthcare program in Costa Rica. Key informants acknowledge the impact made by those earlier programs: "The [Health Ministry's] Rural Health program was the revolution ... A nurse and a technical assistant were the key players. That is when the revolution started: control of parasites, nutrition, latrines, water pumps, vaccinations, and a lot of health education, basic sanitation and 
malaria control measures. It was a very successful program" (Focus group).

By that time, the CCSS had matured sufficiently to transform into an NHS-type system, ready to finance and deliver universal health care through solidarity funding mechanisms, with revenue from general taxation complementing social insurance contributions to cover the costs of those with no capacity to pay. Entitlement to health services would indeed become synonymous with being a Costa Rican. That is probably the single most important feature of the Costa Rican social fabric ${ }^{\mathrm{g}}$.

The primary healthcare reform was not as contested as previous ones were and it was not politically driven as is shown in the lower part of Figure $1^{\mathrm{h}}$. No actor was at the far right representing a high level of opposition, or the far left representing a high level of support. The Presidents of that period did not play a crucial role.

Regarding this reform, multinational donor agencies had agreed to support it, but they did not drive it as the national policy elite managed to negotiate its vision. Key informants confirm that, against the will of the donors, medical doctors were integrated into the basic health teams that spread out over the country: "We could impose our own model, because we do not depend financially on the donors. Other countries do what the donor wants" (Focus group 1). Two grants provided by the World Bank and the Inter-American Development Bank supported the integration of primary health care within the CCSS and the strengthening of the Health Ministry's role as steward.

The reform strategy was that to allocate a health post (EBAIS) per 1,000 households (or 4,000 persons) across the country [10]. Figure 3 shows how health-areas, the sizes of which were related to population density, were established all over the country. This was an important improvement in terms of access to care, as the Health Ministry's primary care program had not achieved universality. Today, $94 \%$ of the population has access to a primary health care post [14] and while not functioning optimally as yet, a referral network from the primary health care teams to the less and more specialized hospitals in the regional and national centres of the country is in place. Overall, evidence has shown that after the third health reform, both general population health and equity improved in Costa Rica [15]. Consequently, while out-of -pocket payments are substantial, no catastrophic health expenditure occurs in Costa Rica [16].

In terms of financing, the third reform triggered the 2000 Workers' Act that made affiliation to the CCSS mandatory also for the self-employed. Until today, the CCSS maintains its financial and managerial autonomy and finances its services based on social insurance contributions complemented by payments by the government to cover the poor. Due to a lack of efficiency in resource management, increasing health care costs related to the demographic and epidemiological transition and to the availability of more and more expensive treatments day by day, the financial situation of the CCSS has become increasingly critical over the past decades. Previously, the expansion process could be temporarily stopped during such times, but today, with UHC principally in place, more structural solutions must be found. While the CCSS has become stricter in controlling evasion and late payment by employers and the working part of the population, over the past decades, the general government regularly has failed to pay its contributions in a timely fashion. Where the expansion of UHC was driven from the highest political level before the 1980s, since then, population demand has apparently contributed more significantly to sustaining it.

The 20th century closed with the CCSS turning sixty years old within an increasingly complex context. The total population was close to four million and the dependence ratio was 59, indicating that children did no longer die of preventable causes and women were not having children in excess of those they wanted. Infant mortality declined to 10.2 per 1,000 live births and total fertility to 2.4 per woman; life expectancy at birth increased to 78 years for both sexes. CCSS population coverage was $88 \%$ and health expenditure reached $8 \%$ of GDP. Social system improvements also continued with $97 \%$ of the population having access to drinkable water [8] (Table 1 and Figure 2).

\section{Remaining challenges}

Costa Rica's health system, as any other in the world, continues to face important challenges. Most key informants agree on the following ones: i) UHC has been achieved, but small pockets of the population are still excluded; ii) UHC once achieved needs to be sustained, which is more difficult today due to the demographic and epidemiological transitions as well as to changing political and economic contexts; iii) the need for improvements in health service quality and better management of waiting lists have become increasingly important in order to control growth in private spending; iv) advances in health technology create demand for new and more expensive interventions; and v) the CCSS finds itself in a self-proclaimed management crisis that has provoked a public debate about its institutional base.

\section{Limitations}

Data collection for this study was limited given that only a few key actors from the first reform period are still alive, and that historic processes in general are scarcely documented in Costa Rica. With regard to the second and third reform period, it was found that differences in key actors' perceptions were sometimes blurred by the 
ongoing rivalry between the CCSS and Health Ministry employees, ever since primary healthcare was integrated in the CCSS scheme. Furthermore, available time and resource constraints limited the number of interviews.

\section{Conclusions}

This study outlines the UHC development process in Costa Rica. Incremental reforms were implemented to build the system in a way that was flexible enough to adjust to the changing context. The CCSS developed from a small institution created for less than $5 \%$ of the population into what is called the largest 'company' in Central America.

The most important lessons observed are: i) population health was high on the political agenda in Costa Rica, in particular before the 1980s when UHC was enacted and the transfer of hospitals to the social security institution took place. Opposition to UHC could therefore be contained through negotiation and the UHC implementation process became incremental and continuous despite the absence of real consensus among the policy elite; ii) UHC in Costa Rica has been placed since the 1960s under the responsibility of the social security institution that enjoys financial and managerial autonomy relative to the general government. This construction has facilitated the UHC policy implementation process to be incremental and continuous; iii) UHC was simultaneously constructed on three pillars that were reciprocally strengthened: increasing population coverage, increasing availability of financial resources based on solidarity financing mechanisms, and increasing coverage with, ultimately, comprehensive health services offering the same benefits to every resident in the country; iv) in particular before the 1980s, the fruits of economic growth were structurally invested in health and other universal social policies, in particular education and sanitation. The social security institution became a flagship of Costa Rica's national development strategy, which reinforced its political importance and contributed to its longer-term sustainability and that of UHC.

UHC has been achieved in Costa Rica not because there was consensus about its importance from the beginning, but because it was pushed from the highest political level within a favourable socio-economic context. Once achieved, UHC became an entitlement for the whole population and started to enjoy broad popular support. The responsibility of implementing the UHC policy fell under a social security institution that enjoys financial and managerial autonomy relative to the general government, which has contributed to the sustainability of the scheme even at times when contextual factors became less favourable.

\section{Endnotes}

${ }^{a}$ The CCSS has always provided medicines with no payment whatsoever.

${ }^{\mathrm{b}} \mathrm{He}$ was a close friend of the President and a very prestigious physician.

${ }^{\mathrm{C}}$ It was also supported by the General Health and Health Ministry's Organic Act.

${ }^{\mathrm{d}}$ The first medical school in Costa Rica was founded in 1961.

${ }^{\mathrm{e}} \mathrm{He}$ enacted two laws to support the reform process and to formalize the rules of the game for actors within the national health system.

${ }^{\mathrm{f}}$ As in many historical instances, important objectives are in conflict. Universal care will improve equity, but it could undermine NHS finances.

${ }^{\mathrm{g}} \mathrm{Co}$-movement of health and education is very important as Costa Rican social accomplishments show.

${ }^{\mathrm{h}}$ Black background for an actor indicates high power, grey means medium power and white means low power.

\section{Abbreviations}

CCSS: Caja Costarricense de seguro social; NHS: National health system; UHC: Universal health coverage.

\section{Competing interests}

The authors declare that they have no competing interests.

\section{Authors' contributions}

The paper is the outcome of a joint study undertaken by its two authors, both having collected the necessary data undertaking key informant interviews and literature reviews. Both authors contributed to drafting and finalizing the paper. Both authors read and approved the final manuscript.

\section{Acknowledgements}

We acknowledge that this study is financially and technically supported by the Alliance for Health Policy and Systems Research, WHO. We also wish to acknowledge the inputs of the Health Systems Financing Department, WHO, and the late Guy Carrin, in particular. The authors want to extend their gratitude to Di Mclntyre and Bhupinder Aulakh for their patience during the writing process and their valuable inputs to the paper.

Received: 7 March 2013 Accepted: 30 July 2013

Published: 21 August 2013

\section{References}

1. World Health Organization: Health Systems; Universal health coverage. http:// www.who.int/healthsystems/universal_health_coverage/en/

2. Global Health Observatory Data Repository: Costa Rica Statistics Summary (2002 - present). http://apps.who.int/gho/data/view.country.6800.

3. Reich M: Computer-Assisted Political Analysis - Policymaker 4 Software, Medicine Transparency Alliance; 2012; 2012. http://www. medicinestransparency.org/?id=600

4. Walt G, Gilson L: Reforming the health sector in developing countries: the central role of policy analysis. Health Policy Plann 1994, 9(4):353-370.

5. Jaramillo J: Historia y Evolución del Seguro Social de Costa Rica. San José: EDNASSS; 2004.

6. Palmer S: From Popular Medicine to Medical Populism. Durham: Duke University Press; 2003.

7. Sojo C: Igualiticos - La Construcción Social de la Desigualdad en Costa Rica. San José, Costa Rica: PNUD; 2010.

8. Sáenz O, Vargas JR, Costa Rica en Cifras II. mimeo, Vargas JR, Saenz JO: Costa Rica en Cifras. San José: MIDEPLAN - PNUD; 1994

9. Rodríguez A: La Reforma de Salud en Costa Rica. Santiago: CEPAL; 2005 
10. Mata L, Rosero-Bixby L: National Health and Social Development in Costa Rica: A Case Study of Intersectorial Action. Technical Paper N.13. Washington, DC: Pan American Health Organization; 1988.

11. Mohs E: La Reforma del Sector Salud en Costa Rica Durante la Década del 70. San José: UNICEF; 1995.

12. Centro Centroamericano de Población (CCP: Indicadores Demográficos de Costa Rica, Tasas de Mortalidad. http://ccp.ucr.ac.cr/observa/CRindicadores/ mortalidad.html.

13. Rosero-Bixby L: Determinantes del descenso de la mortalidad infantil en Costa Rica. Boletín de la OPS 1985, 99(5):510-527.

14. Caja Costarricense de Seguro Social: Blog de Noticias; CCSS ofrece cobertura con EBAIS al 94\% de la población; 2012; 2012. http://www.ccss. sa.cr/noticias/index/32-/379-ccss-ofrece-cobertura-con-ebais-al-94de-la-poblacion.

15. Rosero L: Evaluación del Impacto de la Reforma del Sector de la Salud en Costa Rica Mediante un Estudio Cuasi-Experimental. San José: Revista Panamericana de Salud Pública; 2004.

16. Zúñiga-Brenes MP, Vargas JR, Vindas A: Out-of-Pocket and Catastrophic Health Expenditure Puzzle - The Costa Rican Experience. Working Paper Health Financing Volume 1; Mexico City: Funsalud; 2009; 2009. http://www.funsalud. org.mx/competitividad/financiamiento/Documentos/Working\%20paper\% 20uno/Costa\%20Rica\%20WP1.pdf.

doi:10.1186/1478-4505-11-28

Cite this article as: Vargas and Muiser: Promoting universal financial protection: a policy analysis of universal health coverage in Costa Rica (1940-2000). Health Research Policy and Systems 2013 11:28.

\section{Submit your next manuscript to BioMed Central and take full advantage of:}

- Convenient online submission

- Thorough peer review

- No space constraints or color figure charges

- Immediate publication on acceptance

- Inclusion in PubMed, CAS, Scopus and Google Scholar

- Research which is freely available for redistribution 